\title{
Government Policy and Performance of Small and Medium Business Management
}

\author{
Anthony Abiodun Eniola \\ Department of Business Management, University of Malaysia \\ Email: tony42003@yahoo.co.uk \\ Dr. Harry Entebang \\ Department of Business Management, University of Malaysia \\ Email: harryentebang@yahoo.com
}

DOI: 10.6007/IJARBSS/v5-i2/1481 URL: http://dx.doi.org/10.6007/IJARBSS/v5-i2/1481

\begin{abstract}
It is recorded that 99 per cent of the business bodies in Nigeria are MSMEs which has been an instrumental component in GDP and hub for work opportunities. Even so the identification of the important roles SMEs play in Nigeria, their evolution is mostly bounded by a number of elements, such as the existence of laws, ordinances, and rules that frustrate the growth of the sector. The study reviews the relationship between government policies and small and medium enterprises (SMEs) performance in Nigeria. The study offered some relevant recommendations to policy makers, entrepreneurs, and SME managers to ensure the appropriate scheme to improve the SME sector in Nigeria.
\end{abstract}

Keywords: SME; performance; government policy

\section{Introduction}

The point of convergence of this study is the small and medium enterprise performance as the key economic sector in both developed and emerging economies (Altenburg \& Eckhardt, 2006; Lumpkin \& Dess, 1996; Wiklund \& Shepherd, 2005). The vast majority of firms globally is SMEs, and they play a significant role in the economy (Brush \& Vanderwerf, 1992; Lumpkin \& Dess, 1996; Wiklund \& Shepherd, 2005). This means SME serves as an initial source of motivation for economic power. This assertion is further clearly demonstrated by the fact that the backbone of the European economy is SMEs which is about 98 per cent of the enterprises in the EU. In 2012, SMEs employ 67 per cent of the European workforce and generate 58 per cent of the revenue. The formal SME sector contributes 33 per cent to gross domestic product (GDP) and accounts for about 45 per cent of total employment in developing countries (IFC, 2010). SMls in the quarrying and mining, manufacturing, energy, gas and water sectors are of 